\title{
Conjugated linoleic acids attenuate FSH- and IGF1-stimulated cell proliferation; IGF1, GATA4, and aromatase expression; and estradiol-17 $\beta$ production in buffalo granulosa cells involving PPAR $\gamma$, PTEN, and PI3K/Akt
}

\author{
Isha Sharma and Dheer Singh \\ Animal Biochemistry Division, Molecular Endocrinology Laboratory, National Dairy Research Institute (NDRI), \\ Karnal 132001, Haryana, India \\ Correspondence should be addressed to D Singh; Email: dheer@ndri.res.in
}

\begin{abstract}
Conjugated linoleic acid (CLA) has drawn much interest in last two decades in the area ranging from anticancer activity to obesity. A number of research papers have been published recently with regard to CLA's additional biological functions as reproductive benefits. However, not much is known how this mixture of isomeric compounds mediates its beneficial effects particularly on fertility. In this study, we demonstrated the cross talk between downstream signaling of CLA and important hormone regulators of endocrine system, i.e. FSH and IGF1, on buffalo granulosa cell function (proliferation and steroidogenesis). Experiments were performed in primary serum-free buffalo granulosa cell culture, where cells were incubated with CLA in combination with FSH (25 ng/ml) and IGF1 (50 ng/ml). Results showed that $10 \mu \mathrm{M}$ CLA inhibits FSH- and IGF1-induced granulosa cell proliferation; aromatase, GATA4, and IGF1 mRNA; and estradiol$17 \beta$ production. Western blot analysis of total cell lysates revealed that CLA intervenes the IGF1 signaling by decreasing p-Akt. In addition, CLA was found to upregulate peroxisome proliferator-activated receptor-gamma (PPARG) and phosphatase and tensin homolog (PTEN) level in granulosa cells. Further study using PPARG- and PTEN-specific inhibitors supports the potential role of CLA in granulosa cell proliferation and steroidogenesis involving PPARG, PTEN, and PI3K/Akt pathway.

Reproduction (2012) 144 373-383
\end{abstract}

\section{Introduction}

Conjugated linoleic acid (CLA) is the common element that belongs to a group of C18 fatty acids with two double bonds exhibiting strong nutritional benefits in a variety of animal models (Belury 2002). CLA is a naturally occurring fatty acid produced in the rumen of ruminant animals by the fermentative bacteria, which isomerizes linoleic acid into CLA (Kepler et al. 1970), and is naturally found in food such as milk fat and meat of ruminant animals. A number of studies have supported the role of CLA as anticarcinogenic (Devery et al. 2001, Pariza et al. 2001), antiatherogenic (Lee et al. 1994, Nicolosi et al. 1997), antidiabetic (Houseknecht et al. 1998), and antiobesity (Park et al. 1997) agent.

Dietary $n-3$ polyunsaturated fatty acids (PUFAs) increase systemic circulation of cholesterol as well as the size of corpus luteum in cows. Marei et al. (2009) showed that linoleic acid influenced follicular development. It has been reported that follicular fluid lipid profile in cows fluctuates according to follicle dominance and stage of estrous cycle (Orsi et al. 2005). There is difference in metabolomic strategies opted by subordinate and dominant follicles, as it has been shown that linoleic acid concentration is higher in dominant follicle (Revelli et al. 2009). In feeding practice, CLA supplements are used to decrease milk fat excretion in early lactation dairy animals to save energy in order to counteract the physiological negative energy balance (Von Soosten et al. 2011) that is most often characterized in postpartum period. Fertility in this period is mostly comprised by incidence of anestrous, which is superiorly determined by fate of dominant follicle. However, high dose of CLA was given to nutritionally manage anestrous problem that arises as a result of negative energy balance (Odens et al. 2007). In spite of the abundance of studies reporting that CLA is a key dietary supplement in animals, the molecular mechanisms that facilitate its beneficial effects are not currently well understood.

Maintenance of fertility in animal requires supreme cooperation of gonadotropins and intraovarian regulators. Among all of them, insulin-like growth factor 1 (IGF1) and its signaling pathways play the critical role. In particular, activation of the PI3K or the MAPK pathway by IGF1 has been reported to not only stimulate 
proliferation but also differentiation and/or cell survival depending on the cell type (Butt et al. 1999, Poretsky et al. 1999). Phosphatase and tensin homolog (PTEN) is a well-established negative regulator of this pathway, as it antagonizes the activity of PI3K (Maehama \& Dixon 1998).

Dietary nutrients like CLA control the metabolism by activating peroxisome proliferator-activated receptor- $\gamma$ (PPARG (PPAR $\gamma)$ ), a nuclear hormone receptor expressed throughout the body. PPARG expression and its implication in ovarian function like steroidogenesis, differentiation, and tissue remodeling have been well established (Komar 2005). In addition, several reports suggested a relationship between PPARG and PTEN signaling in human hepatocellular carcinoma cell line (Cao et al. 2007). Also the studies conducted on human gastric cancer cells speculated that PTEN suppresses the cell growth, at least in part, via disturbing the function (Akt signaling) as well as expression of the IGF system (Yi et al. 2005). Consequently, it can be hypothesized that effects are mediated by CLA on fertility through multiple signaling pathways, including PI3K pathway. Therefore, in this study, we explored whether CLA affects granulosa cell functioning by recruiting PTEN as a mediator molecule. In addition, to verify this hypothesis, this study investigated the effects of CLA on granulosa cell function and its underlying possible mechanism.

\section{Results}

\section{Inhibition of FSH- and IGF1-induced cell proliferation by CLA treatment}

Cell proliferation assay using 3-(4,5-dimethylthiazol-2-yl)2,5-diphenyl tetrazolium bromide (MTT) was carried out in cells treated as described in the Materials and methods section. FSH $(25 \mathrm{ng} / \mathrm{ml})$ and IGF1 $(50 \mathrm{ng} / \mathrm{ml})$ alone (dose as optimized earlier) significantly $(P<0.001)$ increased the cell number. Treatment with $\mathrm{FSH}(25 \mathrm{ng} / \mathrm{ml})$ along with IGF1 $(50 \mathrm{ng} / \mathrm{ml})$ showed synergistic increase in cell number (Table 1). However, CLA cotreatment had abolished FSH- and IGF1-induced cell proliferation compared with control (unstimulated cells). However, PPARG antagonist was found to increase cell proliferation significantly $(P<0.001)$.

\section{Dose- and time-dependent effect of CLA on PPARG and PTEN expression in primary cultured buffalo granulosa cell}

Dose- and time-dependent effect of CLA on the expression of PPARG and PTEN has been shown in Fig. 1A, B and C. Result showed that all the doses of CLA $(10,25$, and $50 \mu \mathrm{M})$ studied were found to increase PPARG significantly $(P<0.001)$, thus the highest expression of PPARG was observed at $10 \mu \mathrm{M}$. CLA $(10 \mu \mathrm{M})$ was found to induce PPARG at 24 and $48 \mathrm{~h}$, but
Table 1 Cell proliferation assay.

\begin{tabular}{lc}
\hline Treatment & Absorbance \\
\hline Control & $1.16 \pm 0.08^{\mathrm{c}}$ \\
FSH & $1.99 \pm 0.05^{\mathrm{b}}$ \\
IGF1 & $2.33 \pm 0.04^{\mathrm{a}, \mathrm{b}}$ \\
FSH + IGF1 & $2.55 \pm 0.03^{\mathrm{a}}$ \\
FSH+CLA & $0.77 \pm 0.05^{\mathrm{c}}$ \\
IGF1+CLA & $0.73 \pm 0.05^{\mathrm{c}}$ \\
FSH + IGF1+CLA & $0.91 \pm 0.09^{\mathrm{c}}$ \\
CLA & $0.77 \pm 0.03^{\mathrm{c}}$ \\
GW9662 & $2.60 \pm 0.01^{\mathrm{a}}$ \\
CLA + GW9662 & $1.99 \pm 0.04^{\mathrm{b}}$ \\
\hline
\end{tabular}

Granulosa cells were treated with FSH $(25 \mathrm{ng} / \mathrm{ml})$, IGF1 $(50 \mathrm{ng} / \mathrm{ml})$, CLA $(10 \mu \mathrm{M})$, GW9662 $(1 \mu \mathrm{M})$ alone, or in combination for $48 \mathrm{~h}$ in serum-free culture. Cell proliferation was assessed by Cell Titer 96 Aqueous One Solution (Promega) and the values are given as absorbance values. Values are mean \pm s.E.M. of three independent cultures. Figures with different letters differ significantly at $P<0.001$.

maximum induction was observed at $48 \mathrm{~h}$. A similar effect of CLA on PTEN expression was observed and $10 \mu \mathrm{M}$ CLA was found to increase the expression of PTEN to a maximum at both mRNA and protein level (Fig. 2A and B). The effect of CLA on both PPARG and PTEN was found to be reversed when cells were treated alone or cotreated with 1 and $10 \mu \mathrm{M}$ of antagonist (GW9662) while the effect of antagonist was maximum at $1 \mu \mathrm{M}$. Hence, $10 \mu \mathrm{M}$ CLA, $1 \mu \mathrm{M}$ GW9662, and $48 \mathrm{~h}$ of treatment period had been chosen for subsequent experiment. Further, we checked the effect of CLA on PPARG and PTEN expression in cells treated with or without FSH $(25 \mathrm{ng} / \mathrm{ml})$ and IGF1 $(50 \mathrm{ng} / \mathrm{ml})$ for $48 \mathrm{~h}$. Real-time expression data showed that CLA increased $P P A R G$ and PTEN expression significantly $(P<0.001)$ in the cells treated with CLA alone or in combination with FSH and IGF1, while FSH and IGF1 alone failed to induce the PPARG and PTEN expression compared with $\mathrm{CLA}$ alone (Fig. $3 \mathrm{~A}$ and $\mathrm{B}$ ).

\section{$C L A$ reduces $F S H$ - and IGF1-induced IGF1, aromatase, and GATA4 expression and estradiol-17 $\beta$ synthesis}

Treatment of FSH $(25 \mathrm{ng} / \mathrm{ml})$, IGF1 (50 ng/ml), for $48 \mathrm{~h}$ alone, or in combination increased IGF1 $(P<0.001)$, aromatase $(P<0.001)$, and GATA4 $(P<0.001)$ mRNA significantly compared with control. Cells treated with CLA alone decreased the genes (CYP19A1 (CYP19) and GATA4) significantly in comparison with control and FSH, IGF1, and FSH + IGF1, while in the case of control, some region of significance is shared (as marked with the same letter as well as different letters). IGF1 transcript abundance goes down when cells were treated with CLA alone or in combination with FSH, IGF1, and FSH+ IGF1 with a share in the region of statistical significance (Fig. 4A). CLA downregulated the FSH- and FSH + IGF1induced CYP19A1 gene expression, whereas CLA did not alter the IGF1-stimulated CYP19A1 (Fig. 4B). Additionally, a similar response was observed in hormone (estradiol-17 $\beta\left(E_{2}\right)$ ) production. Consistent 


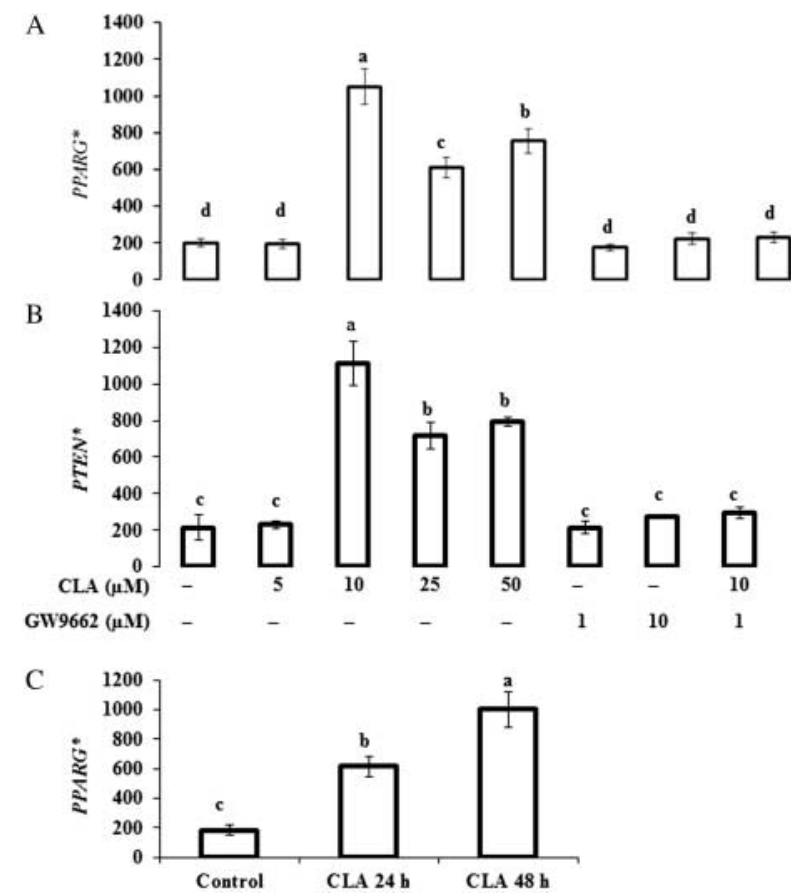

Figure 1 Effects of CLA on PPARG and PTEN transcripts level in cultured buffalo granulosa cell. Cells were cultured for initial $48 \mathrm{~h}$ in serum-free condition as described in the Materials and Methods section followed by treatment with different doses of CLA $(10 \mu \mathrm{M})$, GW9662 $(1 \mu \mathrm{M})$ alone, or in combination for next $48 \mathrm{~h}$. Total RNA was isolated for analysis of PPARG (A) and PTEN (B) transcripts, and also for PPARG induction at two time point 24 and $48 \mathrm{~h}(\mathrm{C}) .{ }^{*}$ Gene transcript (copy no. $\times 10^{3} / \mu$ g RNA). Copy number was calculated and normalized to initial amount of RNA used for cDNA preparation. Results are expressed as \pm s.E.M. of three independent experiments. Bars with different letters indicate significantly difference $(P<0.001)$. In each experiment, measures were obtained as the mean of three replicates.

with the aromatase expression pattern, $\mathrm{FSH}$ - and IGF1-induced $E_{2}$ production was significantly $(P<0.001)$ reduced by CLA treatment. CLA downregulated the $\mathrm{FSH}$-stimulated $\mathrm{E}_{2}$ production to the level of control. However, CLA could not alter the IGF1stimulated CYP19A1 but had shown to decrease the $\mathrm{E}_{2}$ production. Again CLA effect alone was more potent in decreasing $E_{2}$ production (Fig. 5). Likewise, GW9662 did not have any significant effect on gene expression and $\mathrm{E}_{2}$ production.

\section{CLA pretreatment inhibits FSH- and IGF1-induced phosphorylation of $A K T$}

Densitometric analysis of immunoblot showed that IGF1 $(50 \mathrm{ng} / \mathrm{ml})$ alone and in combination with FSH $(25 \mathrm{ng} / \mathrm{ml})$ induced phosphorylation of Akt in cells without CLA pretreatment (Figs 6, 7A and B). In Fig. 7A, unstimulated cells and stimulated cells with FSH showed same level of p-Akt. When cells were incubated with CLA for $48 \mathrm{~h}$ followed by treatment with $\mathrm{FSH}$, IGF1 alone, or in combination for $30 \mathrm{~min}$, it was observed that CLA in combination with FSH, IGF1 alone, or in combination with FSH+IGF1 diminished p-Akt while dephosphorylating effect was more pronounced in cells treated with CLA alone. PTEN and p-Akt protein level shares inverse relationship and the same had been observed in immunoblotting. GW9662 revived the p-AKT to the level of unstimulated cells.

\section{Inhibition of PTEN by bpV(pic) compound and revival of Akt phosphorylation}

Result of granulosa cells treated with CLA in the presence or absence of $\mathrm{bpV}$ (pic) for $30 \mathrm{~min}$ has been shown in Fig. $7 \mathrm{C}$ and D. It was observed that PTEN was downregulated in cells pretreated with bpV(pic), which was further characterized by revival of $p$-Akt to the level of control. The revival in phosphorylation of Akt after incubation with PTEN inhibitor was comparable to

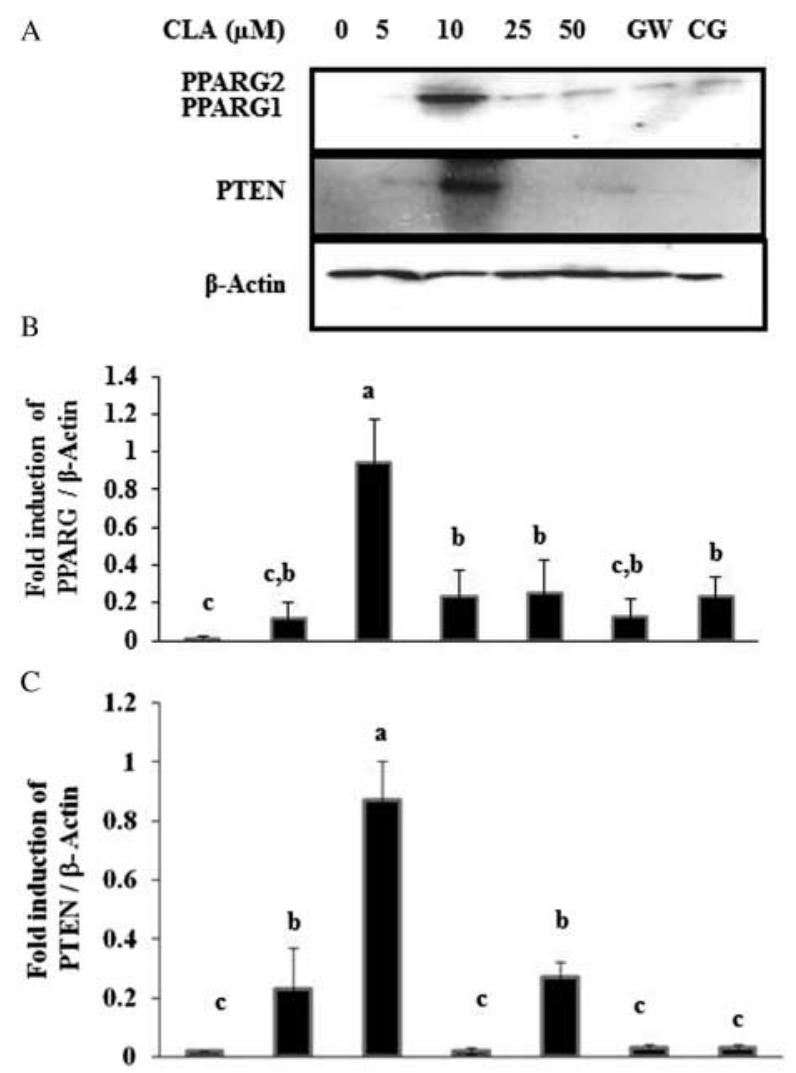

Figure 2 Dose-dependent induction of PPARG and PTEN in cultured buffalo granulosa cells. Cells were cultured for initial $48 \mathrm{~h}$ in serum-free condition as described in the Materials and Methods section followed by treatment with different doses of CLA $(10 \mu \mathrm{M})$, GW9662 $(1 \mu \mathrm{M})$ alone, or in combination for next $48 \mathrm{~h}$. The cells were collected for protein isolation and subsequently followed by western analysis using antPPARG Ab (top), anti-PTEN Ab (middle), and anti- $\beta$-actin (bottom, used as internal control) antibodies. (A) Immunoblot presents both isoforms of PPARG (1 and 2) and PTEN. (B and C) Densitometric analysis of PPARG and PTEN was done, respectively, using $\beta$-actin as an internal control. Bars with different letters indicate significant difference at $P<0.001$. Results are expressed as \pm S.E.M. of three independent experiments. 

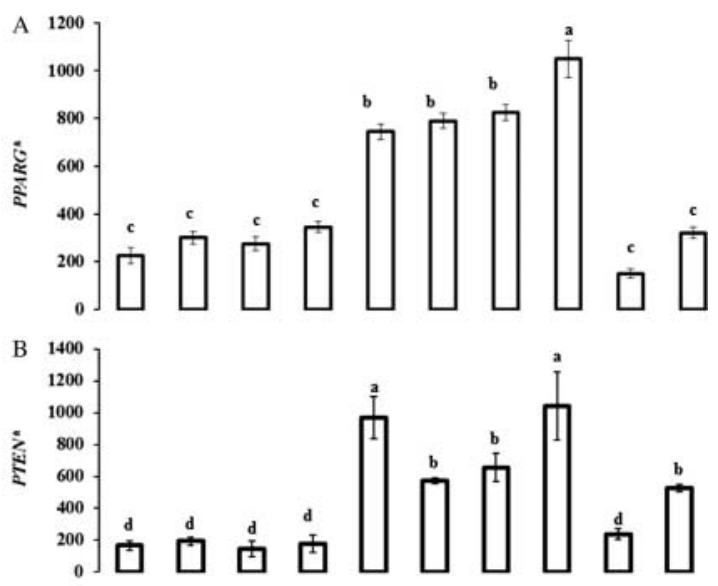

$\begin{array}{rllllllllll}\text { FSH }(25 \mathrm{ng} / \mathrm{ml}) & - & + & - & + & + & - & + & - & - & - \\ \text { IGF1 }(50 \mathrm{ng} / \mathrm{ml}) & - & - & + & + & - & + & + & - & - & - \\ \text { CLA }(10 \mu \mathrm{MM}) & - & - & - & - & + & + & + & + & - & + \\ \text { GW9662 }(1 \mu \mathrm{M}) & - & - & - & - & - & - & - & - & + & +\end{array}$

Figure 3 Effect of CLA, FSH, IGF1, and GW9662 on PPARG (A) and PTEN (B) transcripts in cultured buffalo granulosa cells. Total RNA was isolated from cultured granulosa cell treated with or without CLA $(10 \mu \mathrm{M})$ for $48 \mathrm{~h}$ in the presence or absence of FSH $(25 \mathrm{ng} / \mathrm{ml})$, IGF1 $(50 \mathrm{ng} / \mathrm{ml})$, and GW9662 $(1 \mu \mathrm{M})$ as shown in the figure and described in the Materials and Methods section. *Gene transcript (copy no. $\times 10^{3} / \mu \mathrm{g}$ RNA). Copy number was calculated and normalized to initial amount of RNA used for CDNA preparation. Results are expressed as \pm s.E.M. of three independent experiments. Bars with different letters differ significantly at $P<0.001$. In each experiment, measures were obtained as the mean of three replicates.

control $(P<0.001)$. However, PTEN inhibitor treatment abolished PTEN expression to the level of control. In contrast, CLA alone significantly upregulates $(P<0.001$; Fig. 7C and D) PTEN expression.

\section{Discussion}

In this study, we have demonstrated that CLA increased PTEN expression through activation of PPARG in granulosa cells, which further attenuated the phosphorylation of Akt and thereby regulating granulosa cell functioning (proliferation and steroidogenesis). A number of reports indicated a correlation between nutrition supplements and improved fertility. Renaville et al. (2008) recently demonstrated that intrafollicular CLA level increased in dominant follicle, compared with subordinate follicle. Lipid profile in preovulatory follicle plays detrimental role in assessing follicle rupture, oocyte quality, and its fertilization potential (Singh \& Sinclair 2007, Sinclair et al. 2008, Revelli et al. 2009). Fertility in postpartum period is a major concern because after parturition most of the nutrients are driven toward milk production than follicular maturation (Baumen \& Currie 1980, Leroy et al. 2008). Dietary supplements like CLA are given during this stage, but the mechanism that leads to subsequent ovulation from dominant follicle as a result of treatment is not completely understood.
Recognizing these gaps, we have demonstrated here a serial connection between CLA, PPARG, and PTEN with an inverse relationship between PTEN and p-Akt. Result also showed that CLA disrupts the IGF1 signaling by recruiting PTEN as an intervening molecule, which is upregulated after PPARG induction.

In HT-29 cells, CLA is known to negatively regulate the levels of IGF1, mature IGF1R, and subsequent activation of Akt (Kim et al. 2003). There is reasonable possibility that inhibition of IGF1 signaling may be one of the mechanism by which CLA inhibits cancer cell growth. Our result also supports the functional relevance of CLA in ovary through a signaling mechanism in relation to level of p-Akt. In addition, preliminary data from our laboratory showed that PI3K/Akt pathway mainly contributes to steroidogenesis in buffalo granulosa cell than MAP kinase pathway and the same has been reported in bovine granulosa cell (Murugan et al. 2010). Our results showed that unstimulated cells and stimulated cells with FSH $(25 \mathrm{ng} / \mathrm{ml})$ have same level of p-Akt at day 4 . The possible reason behind this observed
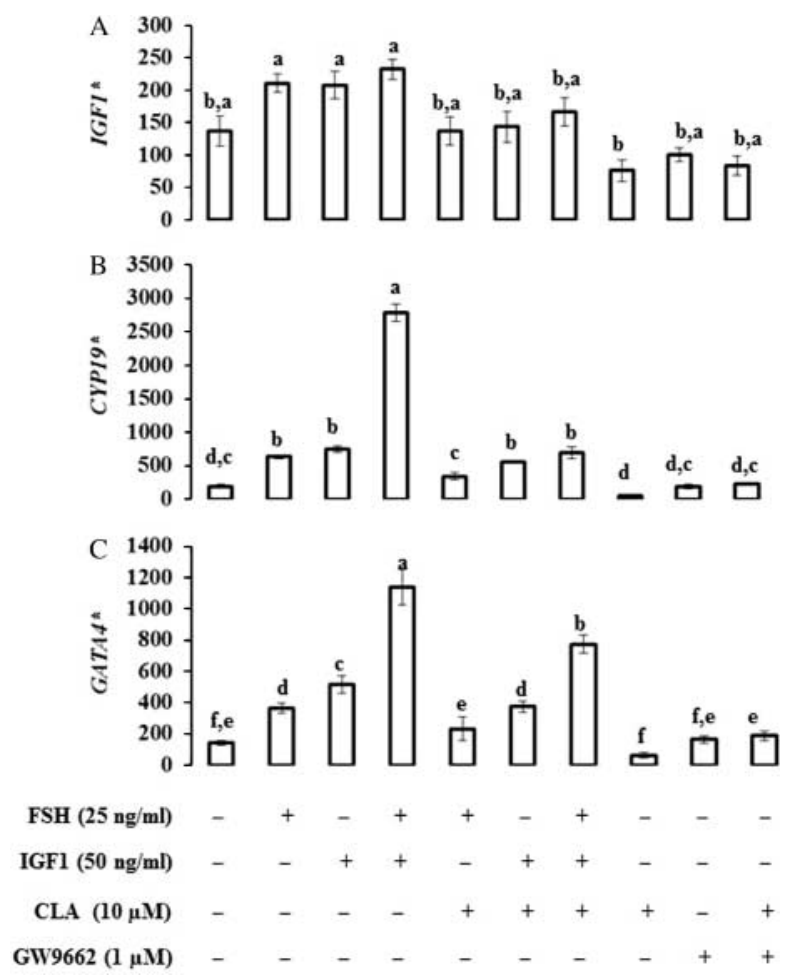

Figure 4 Effect of CLA, FSH, IGF1, and GW9662 on IGF1 (A), CYP19A1 (B), and GATA4 (C) transcripts in cultured buffalo granulosa cells. Total RNA isolated from cultured granulosa cells were treated with or without CLA $(10 \mu \mathrm{M})$ for $48 \mathrm{~h}$ in the presence or absence of FSH $(25 \mathrm{ng} / \mathrm{ml})$, IGF1 $(50 \mathrm{ng} / \mathrm{ml})$, and GW9662 $(1 \mu \mathrm{M})$ as shown in the figure and described in the Materials and Methods section. *Gene transcript (copy no. $\times 10^{3} / \mu \mathrm{g}$ RNA). Copy number was calculated and normalized to initial amount of RNA used for cDNA preparation. Results are expressed as \pm s.E.M. of three independent experiments. Bars with different letters differ significantly at $P<0.001$. In each experiment, measures were obtained as the mean of three replicates. 


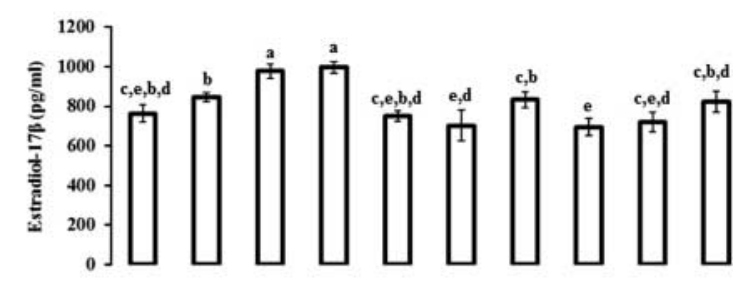

$\begin{array}{rllllllllll}\text { FSH }(25 \mathrm{ng} / \mathrm{ml}) & - & + & - & + & + & - & + & - & - & - \\ \text { IGF1 }(50 \mathrm{ng} / \mathrm{ml}) & - & - & + & + & - & + & + & - & - & - \\ \text { CLA }(10 \mu \mathrm{MM}) & - & - & - & - & + & + & + & + & - & + \\ \text { GW9662 }(1 \mu \mathrm{M}) & - & - & - & - & - & - & - & - & +\end{array}$

Figure 5 Effect of CLA on estradiol- $17 \beta$ content. Cells were treated with or without CLA $(10 \mu \mathrm{M})$ for $48 \mathrm{~h}$ in the presence or absence of $\mathrm{FSH}$, IGF1, and GW9662 as shown in the figure and described in the Materials and methods section. Hormone was estimated using ELISA. Results are expressed as \pm s.E.M. of three independent experiments. Bars with different letters indicate significantly difference $(P<0.001)$. In each experiment, measures were obtained as the mean of three replicates.

difference could be due to IGF1, which is primarily involved in the PI3K signaling cascade for phosphorylation of Akt instead of FSH (Murugan et al. 2010). In goat granulosa cells, linoleic and oleic acid had no effect on AMPK phosphorylation, whereas they rapidly increased MAPK ERK1/2 phosphorylation, and inhibitor studies have further validated these findings depicting the involvement of fatty acids in improving ovarian steroidogenesis through the MAPK ERK1/2 signaling pathway (Coyral-Castle et al. 2010). However, we did not assess the phosphorylation status of MAPK ERK $1 / 2$ protein, as it is not the major pathway operating (Murugan et al. 2010) here, and hence, we have aimed the experiments focusing on p-Akt level only. Our results suggest a possible involvement of CLA that interferes with FSH- and IGF1-stimulated pathway involved in ovarian steroidogenesis in granulosa cell including downregulation of IGF1, aromatase, and GATA4 mRNA and reduced phosphorylation of Akt, hence diminished $E_{2}$ production. However, CLA did not decrease the IGF1-stimulated IGF1 and CYP19A1 but had shown to decrease the $E_{2}$ level. It could be observed as an interesting finding of this study which showed that CLA primarily affects the ovarian steroidogenesis by decreasing the IGF1 mRNA. Accordingly, when cells were treated with CLA along with IGF1, one-way CLA decreases the IGF1 synthesis while IGF1 cotreatment neutralizes its effect and that is why CLA+IGF1 treatment does not have much impact while CLA alone significantly decreased the IGF1 mRNA. However, it is difficult to correlate hormone and mRNA level as hormone accumulates and is stable while mRNA is not so stable compared with hormones. Moreover, it is a well-established fact that there is frequently a lack of concordance between mRNA and protein concentration data (Gygi et al. 1999, Schmidt et al. 2007). Furthermore, we have also demonstrated that CLA effects on

steroidogenesis are mediated through accumulation of PPARG, which acts as a novel signal for integration of energy balance and reproduction basically by sensing the nutritional status in the microenvironment of follicle (Fernandez-Fernandez et al. 2006). The activated PPARG initiates signal transduction via recruiting phosphates like PTEN (Lee et al. 2006). Activation of PTEN propagates signal to regulate several cellular and metabolic functions such as cell proliferation and phosphorylation status of metabolic enzymes involved in glucose metabolism. Our results showed that CLA induced PTEN expression, which consequently attenuated the endogenous IGF1 transcription as well as $\mathrm{FSH}$ - and IGF1-induced phosphorylation of Akt and thereby granulosa cell steroidogenesis and proliferation. Our experiments had shown that CLA in combination with FSH and IGF1 have reduced the phosphorylation of Akt, but the effects were more pronounced when cells were incubated with CLA alone because CLA alone significantly induced the PTEN expression.

Throughout the study, we have used the granulosa cells that were $\mathrm{FSH}$ responsive with estrogen dominant and having high CYP19A1 gene expression, i.e. they are not luteinized but $\mathrm{LH}$ responsive with high $\mathrm{LH}$ receptors. As studied in detail earlier, at this stage (day 4), if cells were treated with $\mathrm{LH}, \mathrm{LH}$ downregulates almost all gene in the same fashion, as LH surge downregulates the gene in vivo (Monga et al. 2011). Considering these studies, we treated the cells up to day 4 , as they exhibit phenotypic characteristic features of preovulatory follicle, which were subsequently followed by their tendency to get luteinized in the succeeding days. We are comparing this in vitro-standardized model with in vivo system that day 4 cultured cells have gene expression characteristic of a dominant follicle. This stage of follicle undergoes subsequent transition from high proliferative and less steroidogenic to less proliferative and high steroidogenic form in response to $\mathrm{LH}$, which is the trigger of ovulation and luteinization (Mitwally et al. 1999). In this phase, CYP19A1 expression goes down and PTEN level increases, which is a prerequisite for dominant follicle to ovulate. However, we cannot exactly correlate the present findings with the preovulatory follicle status in postpartum animal, as they are likely to differ in their proliferative potential and kind of lipid profile in follicular fluid, which further depend on the nutritional status of animal. However, problem remains of sampling from the animals falling in the category of negative energy balance after first calving. Therefore, further studies using granulosa cells from these animals and also profiling their lipid composition in follicular fluid reveal detailed functional evaluation of exogenously administered or nutritionally supplemented CLA.

Polycystic ovarian syndrome (PCOS) is the leading cause of infertility and menstrual irregularities in women of reproductive age and is characterized by chronic 


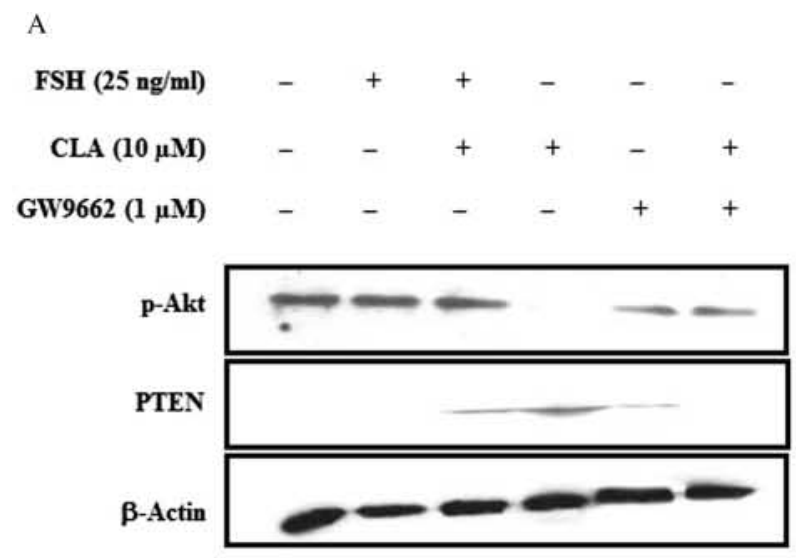

B
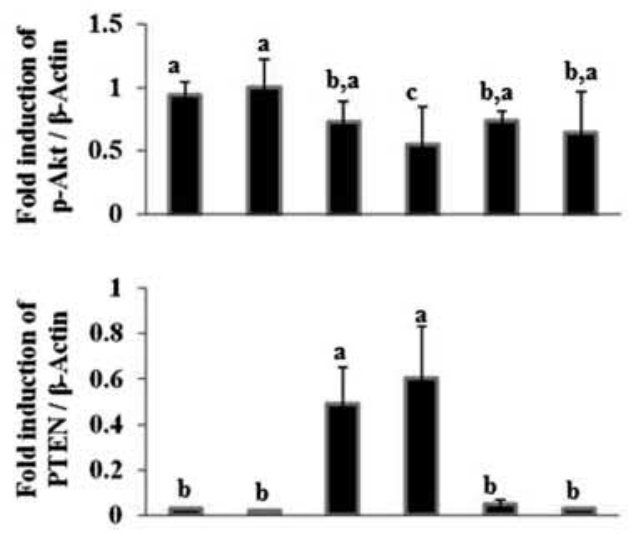

C

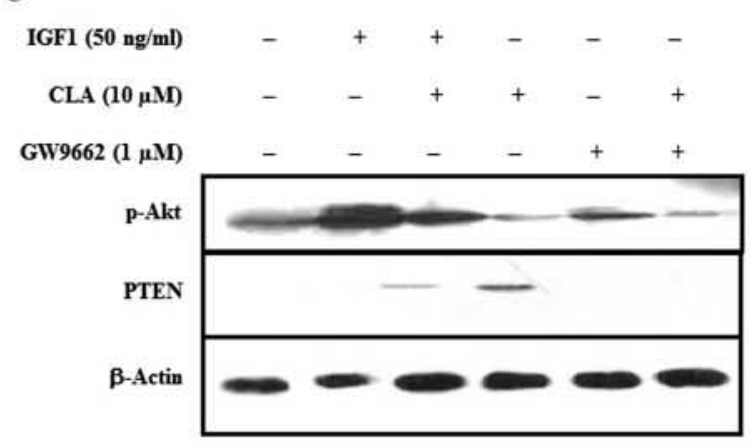

D
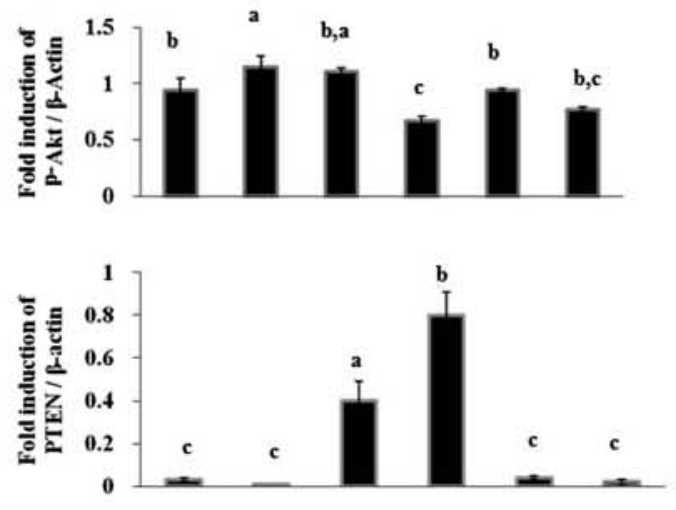

hyperandrogenic anovulation (Rimon et al. 2004). This disorder is mainly characterized with instances of insulin resistance. Thiazolidinediones (TZDs) rosiglitazone or pioglitazone have been shown to improve insulin sensitivity in PCOS (Ehrmann et al. 1997). TZDs are exogenous ligand of PPARG. Hereby, it can be suggested that natural dietary CLA can also be used as a substitute to these synthetic ligands, as rosiglitazone and pioglitazone are currently listed as a Pregnancy Category C drug (i.e. not tested for use during human pregnancy). Some side effects of TZD administration are weight gain, fluid retention (Rubenstrunk et al. 2007), and possible bone demineralization. Present report demonstrates the serum-free cultured buffalo granulosa cell as a model to determine the functional significance of CLA in ovary. These cells share the same characteristic features as shown by human ovarian granulosa cells. And hence, we can relate these studies with the mammalian system including human. Therefore, a better experimental approach is required to clarify the role of CLA in fertility considering a lot many aspects of this molecule not only as a mixture but also as a individual isomer. Considering the present data, we can conclude that CLA exerts its role in preovulatory follicle by the negative correlation of PI3 kinase/PKB signaling pathway. Moreover, PTEN and PPARG inhibitor studies symbolize that CLA takes PPARG-dependent pathway to execute its downstream signaling effects. However, PPARG-independent effects also cannot be denied completely as PUFAs are known to take PPAR-independent pathways (Derecka et al. 2008) and also PPARG inhibitor (GW9662) inhibited the cell growth of human tumor mammary cell line, which supports the existence of PPARG-independent pathways (Seargent et al. 2004).

To the best of our knowledge, as proposed (Fig. 8), this is the first report to demonstrate a novel signaling mechanism opted by CLA in regulating steroidogenesis in any species. In conclusion, this study demonstrated that expression of PTEN was induced by CLA through PPARG-dependent pathway in vitro, which attenuates phosphorylation of Akt, and FSH/IGF1-induced effects on granulosa cell steroidogenesis and proliferation. These findings showed that CLA, therefore, can be

Figure 6 Phosphorylation of Akt and induction of PTEN in cultured buffalo granulosa cells. Cells were cultured as described in the Materials and Methods section. Cells were either left untreated (control) or treated with CLA $(10 \mu \mathrm{M})$, GW9662 $(1 \mu \mathrm{M})$ alone, or in combination for $48 \mathrm{~h}$ followed by stimulation with FSH ( $25 \mathrm{ng} / \mathrm{ml})$ or IGF1 $(50 \mathrm{ng} / \mathrm{ml})$ for $30 \mathrm{~min}$. After that, cells were collected for protein isolation. Immunoblotting was done using anti-p-AktAb (top), anti-PTENAb (middle), and anti- $\beta$-actin $\mathrm{Ab}$ (bottom). Immunoblots present the p-Akt and PTEN (A and C) in cells treated with FSH, IGF1, CLA, and GW9662. Ratio of signal intensity of p-Akt and PTEN (B and D), which was normalized to $\beta$-actin. Results are expressed as \pm s.E.M. of three independent experiments. Bars with different letters indicate significantly difference at $P<0.001$. 
A

$\begin{array}{rrrrrrr}\text { IGF1 }(50 \mathrm{ng} / \mathrm{ml}) & - & + & + & - & - & - \\ \text { FSH }(25 \mathrm{ng} / \mathrm{ml}) & - & + & + & - & - & - \\ \text { CLA }(10 \mu \mathrm{M}) & - & - & + & + & - & + \\ \text { GW9662 }(1 \mu \mathrm{M}) & - & - & - & - & + & +\end{array}$

B
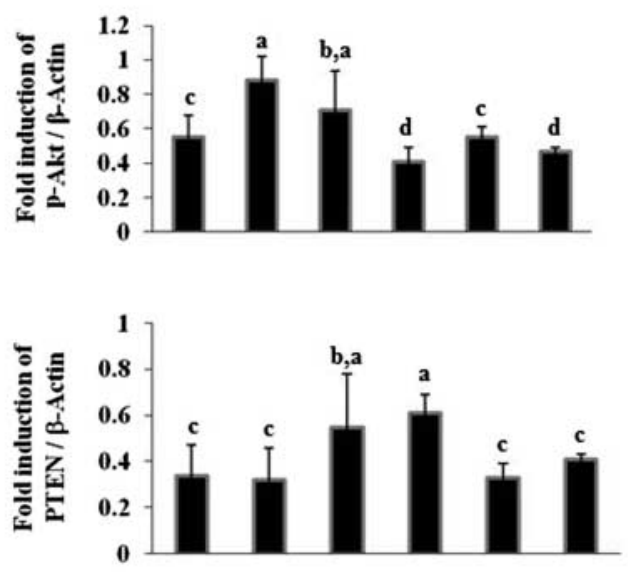

C CLA $(10 \mu \mathrm{M})$

bpV $(10 \mu \mathrm{M})$

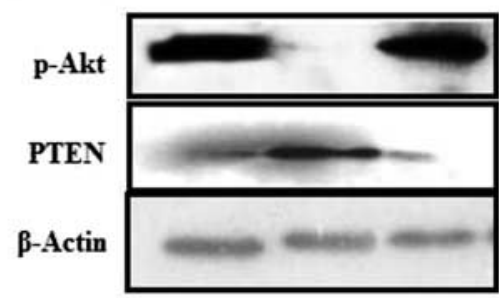

D
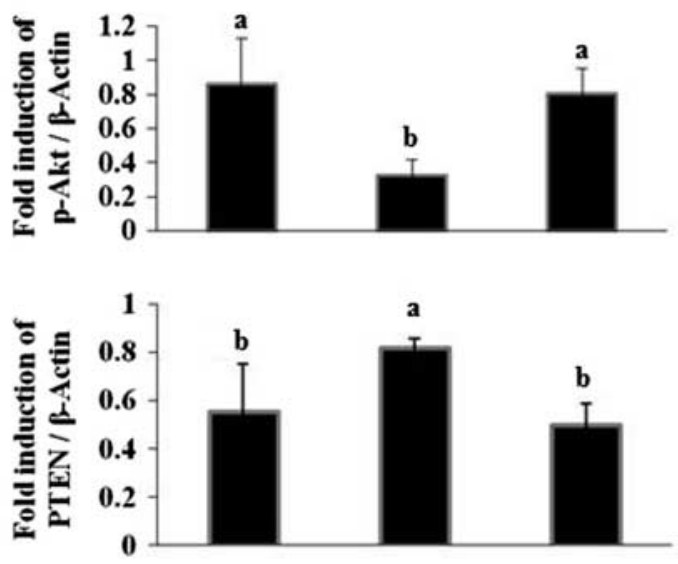

a key regulatory molecule of granulosa cell functioning in preovulatory follicles. Further studies are required to achieve detailed functional analysis of CLA in ovary during different pathophysiological conditions.

\section{Materials and Methods \\ Collection of buffalo ovaries and isolation of granulosa cells}

Buffalo ovaries were collected from commercial abattoir, Delhi. Just after killing animals, ovaries were placed in chilled normal saline $(0.9 \% \mathrm{NaCl})$ containing penicillin $(100 \mathrm{U} / \mathrm{ml})$ and streptomycin $(100 \mu \mathrm{g} / \mathrm{ml})$ and transported to laboratory rapidly (approximately within $4 \mathrm{~h}$ ). All the tissues were washed at least five times in saline, disinfected once in $70 \%$ ethanol for $30 \mathrm{~s}$, then washed again with saline, and processed immediately. Healthy developing follicles were assessed by the presence of vascularized theca externa and clear amber follicular fluid with no debris. Follicular fluid was aspirated from small and medium antral follicles $(<8 \mathrm{~mm})$ using 18 gauge needle and sterile, nontoxic, nonpyrogenic, monoinjected brand syringes (Dispovan, Faridabad, Haryana, India; $2.0 \mathrm{ml}$ ). The fluid was collected in PBS containing penicillin $(100 \mathrm{U} / \mathrm{ml})$, streptomycin $(100 \mu \mathrm{g} / \mathrm{ml})$, and amphotericin B $(1.25 \mu \mathrm{g} / \mathrm{ml})$ in $15 \mathrm{ml}$ centrifuge tube under sterile conditions while continuously maintaining the cells on ice. The granulosa cells were finally separated by centrifugation at low speed ( $200 \mathrm{~g}$ ) for 4-6 min to pellet out the cells. Cell number and viability were estimated in hemocytometer using trypan blue exclusion method. Approximately $70-80 \%$ of cells were found to be viable.

\section{Culture and treatment of granulosa cell}

All the culture reagents were purchased from Sigma-Aldrich, Inc., unless otherwise stated. Cells were seeded in 24-well tissue culture plates (Nunc, Roskilde, Denmark) at a density of $2 \times 10^{5}$ viable cells in $1.0 \mathrm{ml}$ DMEM serum-free culture medium containing L-glutamine $(3 \mathrm{mM})$, protease-free BSA $(1 \mathrm{mg} / \mathrm{ml})$, sodium selenite $(4 \mathrm{ng} / \mathrm{ml})$, transferrin $(2.5 \mu \mathrm{g} / \mathrm{ml})$, androstenedione $(2 \mu \mathrm{M})$, bovine insulin $(10 \mathrm{ng} / \mathrm{ml})$, nonessential amino acid mix $(1.1 \mathrm{mM})$, ovine $\mathrm{FSH}(1 \mathrm{ng} / \mathrm{ml})$, human

Figure 7 Phosphorylation of Akt and induction of PTEN in cultured buffalo granulosa cells in vitro. Cells were cultured as described in the Materials and Methods section and were either left untreated (control) or treated with CLA $(10 \mu \mathrm{M})$, GW9662 $(1 \mu \mathrm{M})$ alone, or in combination for $48 \mathrm{~h}$ followed by stimulation with FSH $(25 \mathrm{ng} / \mathrm{ml})$

+IGF1 $(50 \mathrm{ng} / \mathrm{ml})$ for $30 \mathrm{~min}$. Also cells were incubated with or without bpV(pic) $-10 \mu \mathrm{M}$ for 30 min followed by induction with CLA $(10 \mu \mathrm{M})$ for next $48 \mathrm{~h}$. Cell lysates were prepared followed by immunoblotting. (A) Representative immunoblots showing p-Akt (top), PTEN (middle), and $\beta$-actin (bottom). (B) Histogram presents their respective densitometric signal intensity normalized to the $\beta$-actin. (C) Representative immunoblot showed the effect of bpV(pic) on p-Akt (top), PTEN (middle), and $\beta$-actin (bottom). (D) Ratio of signal intensity of $p$-Akt/ $\beta$-actin. Results are expressed as \pm s.E.M. of three independent experiments. Bars with different letters indicate significantly difference $(P<0.001)$. 


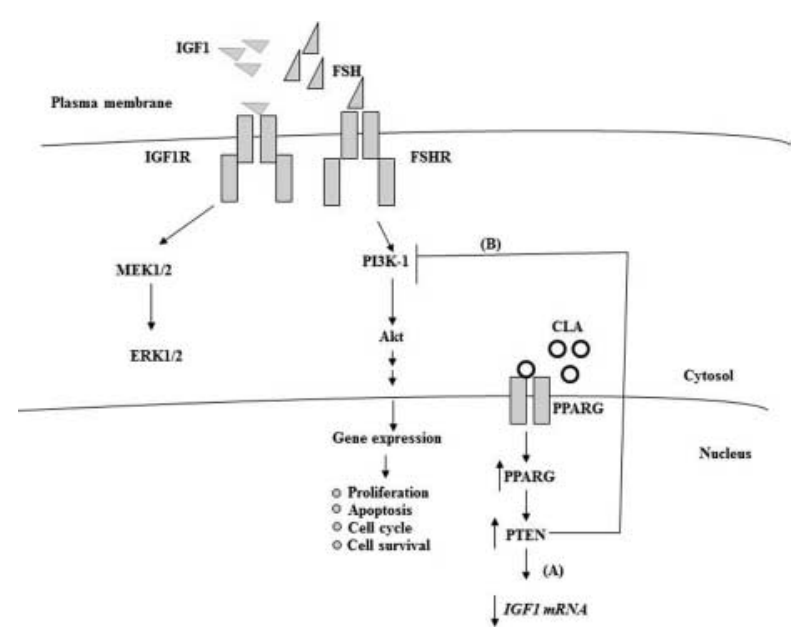

Figure 8 Proposed cross talk between CLA and FSH + IGF1 downstream signaling pathway. In granulosa cell, FSH + IGF1 synergistic effects are indispensable for proliferation and steroidogenesis mainly through PI3K/Akt pathways. CLA binds to nuclear receptor PPARG and induced its expression, which further increased the expression of PTEN and upregulated PTEN, which intervenes IGF1 signaling by two ways: (A) decreasing IGF1 mRNA and (B) dephosphorylating PIP3 to PIP2, which leads to downregulation of $\mathrm{p}$-Akt.

rIGF1 $(1 \mathrm{ng} / \mathrm{ml})$, penicillin $(100 \mathrm{U} / \mathrm{ml})$, and streptomycin $(100 \mu \mathrm{g} / \mathrm{ml})$ and maintained at $37^{\circ} \mathrm{C}$ in $5 \% \mathrm{CO}_{2}, 95 \%$ air as described earlier (Monga et al. 2011).

\section{Experimental design}

To standardize the dose of CLA treatment for PPARG and PTEN induction, after the initial $48 \mathrm{~h}$ of establishment period, the spent media were carefully removed and replaced with fresh medium prepared as earlier including androstenedione but without other hormonal supplements $(1 \mathrm{ng} / \mathrm{ml} \mathrm{FSH}$ and $1 \mathrm{ng} / \mathrm{ml}$ IGF1) as standard. At this stage, cells were either left untreated or treated with different doses of CLA and antagonist (GW9662) as indicated in the figure legends. After a further $48 \mathrm{~h}$ of treatment period, media were carefully removed and stored at $-20^{\circ} \mathrm{C}$ until assayed, and cells from triplicate wells were lysed separately and used for RNA isolation, whereas cells from triplicate wells were collected separately and pooled for protein isolation respectively. CLA dose $(10 \mu \mathrm{M})$, which was found to induce PPARG maximally, was further used to see its effect at two (24 and $48 \mathrm{~h}$ ) time points as indicated in the figure legends. Similarly, to study the effect of CLA on FSH-, IGF1-, and FSH + IGF1-stimulated cell proliferation; IGF1, aromatase, and GATA4 mRNA; and $\mathrm{E}_{2}$ production after the initial $48 \mathrm{~h}$ of establishment period, the spent media were carefully removed and replaced with fresh medium prepared as earlier including androstenedione but without other hormonal supplements $(1 \mathrm{ng} / \mathrm{ml} \mathrm{FSH}$ and $1 \mathrm{ng} / \mathrm{ml} \mathrm{IGF} 1)$ as standard. At this stage, cells were either left untreated or treated with CLA $(10 \mu \mathrm{M})$ and antagonist (1 $\mu \mathrm{M}, \mathrm{GW} 9662)$ alone or in combination, and also cells were cotreated with CLA $(10 \mu \mathrm{M})$ in combination with $\mathrm{FSH}$, IGF1, and FSH + IGF1 as indicated in the figure legends. After a further $48 \mathrm{~h}$ of treatment period, media were carefully removed and stored at $-20^{\circ} \mathrm{C}$ until assayed, cells from triplicate wells were lysed separately, and were used for RNA isolation. In a similar set of experiments, for cell proliferation assay, cells were plated as in 96-well plates, but other aspects of the experimental treatments remained the same.

In another set of experiments, after the initial $48 \mathrm{~h}$ of establishment period, cells were pretreated with CLA $(10 \mu \mathrm{M})$ for next $48 \mathrm{~h}$, then spent media were removed carefully, and cells were further treated with FSH, IGF1, and FSH + IGF1 for $30 \mathrm{~min}$ as described in the figure legends. After treatment, spent media were removed and cells from triplicate wells were collected separately and pooled for immunoblotting of p-Akt and PTEN. The time point of 30 min was chosen specifically for FSH + IGF1-induced Akt phosphorylation experiments because preliminary data of our laboratory using granulsoa cells showed that FSH $(20 \mathrm{ng} / \mathrm{ml})+\mathrm{IGF} 1(50 \mathrm{ng} / \mathrm{ml})$ treatment resulted in peak p-Akt levels from 15 to $60 \mathrm{~min}$.

To evaluate the involvement of PTEN, after the initial $48 \mathrm{~h}$ of establishment period, cells were pretreated with $\mathrm{bpV}$ (pic) $(10 \mu \mathrm{M}$; Cayman, Ann Arbor, MI, USA) for $30 \mathrm{~min}$ and then media were replaced with fresh media as earlier and supplemented with CLA $(10 \mu \mathrm{M})$ and incubated for next $48 \mathrm{~h}$ followed by removal of spent media, and cells from triplicate wells were collected separately and pooled for immunoblotting of p-Akt and PTEN.

\section{Cell proliferation assay}

Growing cells were observed microscopically. Cell proliferation was assayed using Cell Titer 96 Aqueous One Solution Cell Proliferation Assay (Promega) as described earlier (Murugan et al. 2010, Monga et al. 2011). Briefly, $20 \mu \mathrm{l}$ cell proliferation assay solution was added into each well of a 96-well culture plate containing cells in $100 \mu \mathrm{l}$ culture medium. The plates were incubated for $4 \mathrm{~h}$ at $37^{\circ} \mathrm{C}$ in $5 \% \mathrm{CO}_{2}$. At the end of the incubation period, the absorbance was recorded at $490 \mathrm{~nm}$ using a 96-well ELISA plate reader. The absorbance was directly proportional to the number of living cells in culture. Each treatment for the assay was performed in triplicate.

\section{RNA isolation and RT}

Total RNA was isolated using TRIzol (Sigma-Aldrich Co.). Isolated RNA was used immediately for RT-PCR or stored at $-80^{\circ} \mathrm{C}$ until use. The RNA was quantified using nanophotometer, and RNA integrity was evaluated by denaturing agarose gel electrophoresis. A total of $100 \mathrm{ng}$ RNA was used for each of the set of experiments. cDNA synthesis was performed using the first-strand cDNA synthesis kit (Fermentas, St. Leon-Rot, Germany) using random hexamer primers. The reaction mixture contained $100 \mathrm{ng}$ total $\mathrm{RNA}, 1 \mu \mathrm{l}$ random hexamer $(0.2 \mu \mathrm{g} / \mu \mathrm{l})$, and $\mathrm{sH}_{2} \mathrm{O}$ to $11 \mu \mathrm{l}$. The contents were incubated at $65^{\circ} \mathrm{C}$ for $10 \mathrm{~min}$ followed by $2 \mathrm{~min}$ incubation at room temperature. The reagents added further were $4 \mu \mathrm{l} 5 \times$ reaction buffer $(250 \mathrm{mM}$ Tris- $\mathrm{HCl}, \mathrm{pH}$ 8.3; $250 \mathrm{mM} \mathrm{KCl}$, $20 \mathrm{mM} \mathrm{MgCl}_{2}$, and $50 \mathrm{mM}$ dithiothreitol), $1 \mu \mathrm{l}$ RNase inhibitor (20 IU), $2 \mu \mathrm{l}$ dNTP mix $(10 \mathrm{mM})$, and $2 \mu \mathrm{l}$ M-MuLV reverse transcriptase (200 IU) to a final volume of $20 \mu \mathrm{l}$. The contents were incubated at $25^{\circ} \mathrm{C}$ for $10 \mathrm{~min}, 42{ }^{\circ} \mathrm{C}$ for $30 \mathrm{~min}$, and $95^{\circ} \mathrm{C}$ for $3 \mathrm{~min}$. The prepared cDNA was then analyzed using 
Table 2 Primer used for real-time PCR.

\begin{tabular}{|c|c|c|c|}
\hline Name of gene & Primer sequences $\left(5^{\prime}-3^{\prime}\right)$ & Product size & Accession no. \\
\hline PTEN & $\begin{array}{l}\text { FP: GCCACAAAGTGCCTCGTTTACC } \\
\text { RP: AGAAGGCAACTCTGCCAAACAC }\end{array}$ & 120 & XM_613125.4 \\
\hline PPARG & $\begin{array}{l}\text { FP: TCAGTGGAGACCGCCCAGGTT } \\
\text { RP: GAGCTGGGAGGACTCGGGGT }\end{array}$ & 116 & NM_181024.2 \\
\hline CYP19A1 & $\begin{array}{l}\text { FP: CCTGTGCGGGAAAGTACATCGC } \\
\text { RP: TCTTCTCAACGCACCGATCTTG }\end{array}$ & 105 & DQ407274.2 \\
\hline IGF1 & $\begin{array}{l}\text { FP: CATCCTCCTCGCATCTCTTC } \\
\text { RP: ACATCTCCAGCСТCСТCAGA }\end{array}$ & 243 & HQ324241 \\
\hline GATA4 & $\begin{array}{l}\text { FP: AGGCCTCTTGCAATGCGGAAAG } \\
\text { RP: GGACCTGCTGGTGTCTTTGATTTG }\end{array}$ & 86 & NM_001192877.1 \\
\hline
\end{tabular}

PTEN, phosphatase and tensin homolog deleted on chromosome 10; PPARG, peroxisome proliferator-activated receptor- $\gamma$; CYP19A1, cytochrome P450 aromatase; IGF1, insulin-like growth factor 1 .

PCR. Gene-specific primers were used for amplification (Table 2). The primers were designed using NCBI database and the Primer 3 Software (Whitehead Institute for Biomedical Research, Cambridge, MI, USA).

\section{Real-time PCR}

cDNA prepared from 100 ng RNA was amplified with LC 480 SYBR Green master mix (Roche) in a final reaction mixture of $12 \mu \mathrm{l}$. Amplification and quantification were performed using light cycler real-time PCR (Roche Diagnostics) under the following cycling conditions: pre-incubation at $95{ }^{\circ} \mathrm{C}$ for $5 \mathrm{~min}$, followed by 40 cycles of denaturation $95^{\circ} \mathrm{C}$ for $20 \mathrm{~s}$, annealing at $60{ }^{\circ} \mathrm{C}$ for $15 \mathrm{~s}$, and extension at $72{ }^{\circ} \mathrm{C}$ for $15 \mathrm{~s}$. Melting peaks were determined using melting curve analysis in order to ensure the amplification and thus generation of single product. Also, agarose gel electrophoresis analysis (1.5\%) was carried out to determine the length of the amplified PCR product. Cloned PCR products were used to generate standard curves ranging over eight orders of magnitude $\left(2.5 \times 10^{-15}\right.$ $2 \times 10^{-10} \mathrm{~g}$ DNA per reaction) using freshly diluted plasmids every time from the stock concentration of $10^{-9} \mathrm{~g}$ DNA/ $\mu$ l. The standard curve slope was found to be -3.35 while efficiency was 1.98, which is under optimal PCR efficiency range of a slope of -3.3 as per Roche Diagnostics, LC rel. Quantification Software, March 2001 (Weihenstephaner, Freising-Weihenstephaner, Germany). Amplification efficiency was determined from the slope of the log-linear portion of the calibration curve, i.e. PCR efficiency $=10^{(-1 / \text { slope })}-1$, when the logarithm of the initial template concentration (the independent variable) is plotted on the $x$-axis and Cp (the dependent variable) is plotted on the $y$-axis. Copy number was calculated relative to the amount of RNA that was subjected to CDNA preparation. PCR reaction with all the PCR reagents other than the added CDNA was used as a negative control.

\section{Measurement of $E_{2}$}

The concentration of $E_{2}$ was determined using ELISA (Omega Diagnostics, Scotland, UK). The $E_{2}$ standard curve was generated from the standards provided in the kit, which ranged from $0 \mathrm{pg} / \mathrm{ml}-1 \mathrm{ng} / \mathrm{ml}$. The intra- and interassay coefficients of variation for $E_{2}$ assay were 3.4 and $5.32 \%$ respectively. Estimation was performed as per the manufacturer's instructions using $25 \mu \mathrm{l}$ spent medium for hormone estimation. Each treatment was performed in triplicate upon each batch of cells and media from each well were assayed individually.

\section{Immunoblotting}

Cells were washed with ice-cold PBS ( $\mathrm{pH} \mathrm{7.5)} \mathrm{and} \mathrm{the} \mathrm{culture}$ wells were aspirated to dryness. Then, lysis buffer $(63.5 \mathrm{mM}$ Tris- $\mathrm{HCl}(\mathrm{pH} 6.8), 10 \%(\mathrm{v} / \mathrm{v})$ glycerol, 2\% (w/v) SDS, $10 \mu \mathrm{l}$ of $1 \times$ protease inhibitor cocktail (Sigma-Aldrich Co.), and $200 \mathrm{mM}$ sodium orthovanadate) was added to the cells, which were then incubated on ice for $10 \mathrm{~min}$. The cells were scraped from the culture wells into $1.5 \mathrm{ml}$ microfuge tubes and were then boiled at $100{ }^{\circ} \mathrm{C}$ for $5 \mathrm{~min}$ and briefly centrifuged to pellet the cell debris, if present. After determination of approximate protein content using absorbance at $280 \mathrm{~nm}$ (Nanophotometer, Implen, Schatzbogen, München, Germany), bromophenol blue and $\beta$-mercaptoethanol were added to the samples to give final concentrations of $0.02 \%(\mathrm{w} / \mathrm{v})$ and $5 \%(\mathrm{v} / \mathrm{v})$ respectively. The samples were then stored at $-80{ }^{\circ} \mathrm{C}$ until analyzed.

Protein lysates $(100 \mu \mathrm{g})$ were separated by $10 \%$ SDS-PAGE and transferred to polyvinylidene difluoride (Pall Corporation, Port Washington, NY, USA; cat\# 66543) using the wet transfer Trans-Blot assembly (Bio-Rad). Membranes were blocked in Tris-buffered saline (TBS-T; $50 \mathrm{mM}$ Tris, $\mathrm{pH}$ 7.6, $150 \mathrm{mM} \mathrm{NaCl}$, and $1 \%$ Tween 20$)$ containing $5 \%(\mathrm{w} / \mathrm{v})$ nonfat milk for $2 \mathrm{~h}$ at room temperature with gentle agitation. The membrane was then incubated overnight in TBS-TV (TBS-T; $50 \mathrm{mM}$ Tris, $\mathrm{pH} 7.4$, $150 \mathrm{mM} \mathrm{NaCl}, 1 \%$ Tween 20, and $100 \mathrm{mM}$ sodium vandate) with $1 \%$ nonfat milk containing antibodies to p-Akt dilution 1:1000 (Santa Cruz, Santa Cruz, CA, USA; cat\# SC-101629) or PPARG dilution 1:1000 (Santa Cruz, cat\# sc-7273) or PTEN dilution 1:1000 (Santa Cruz, cat\# sc-7974) or $\beta$-actin dilution 1:1000 (Santa Cruz, cat\# sc-47778) and normal mouse IgG (Millipore, Billerica, MA, USA; cat\# 12-371B) with gentle agitation at $4{ }^{\circ} \mathrm{C}$. After incubating the membranes overnight with primary antibody, the membranes were washed and incubated with HRP-conjugated secondary antibodies (Santa Cruz, cat\# sc-2005, sc-2379) in TBS-TV for $2 \mathrm{~h}$ at room temperature and then washed. A chemiluminescent signal was generated using $\mathrm{ECL}$ reagent (ECL, Pierce, Rockford, IL, USA) and membranes were exposed to X-ray film (Kodak biomax light film, Sigma). The housekeeping gene $\beta$-actin was used as a positive loading control. Normal mouse IgG was used as a negative control. 


\section{Statistical analysis}

A one-way ANOVA test was performed to determine the effect of significance followed by Tukey's test to find out the significance of each effect level. All experimental data were presented as the mean \pm s.E.M. of three independent experiments. Bars with different letters indicate significant difference at $P<0.001$. All statistical analysis was performed using SAS System Software (copyright 2009, SAS Institute, Inc., Cary, NC, USA).

\section{Declaration of interest}

The authors declare that there is no conflict of interest that could be perceived as prejudicing the impartiality of the research reported.

\section{Funding}

This work was supported by NDRI SRF Fellowship to I Sharma and Institute's laboratory contingency grant.

\section{Acknowledgements}

The authors thank the Director of National Dairy Research Institute, Karnal, for providing necessary facilities for this work. They also thank Mr Gyan Singh, T-7/8 senior programmer, Data processing Unit, NDRI, for helping in statistical data analysis.

\section{References}

Baumen DE \& Currie WB 1980 Partitioning of nutrients during pregnancy and lactation: a review of mechanisms involving homeostasis and homeorhesis. Journal of Dairy Science 62 1514-1529. (doi:10.3168/jds. S0022-0302(80)83111-0)

Belury MA 2002 Inhibition of carcinogenesis by conjugated linoleic acid: potential mechanisms of action. Journal of Nutritional Biochemistry 132 2995-2998.

Butt AJ, Firth SM \& Baxter RC 1999 The IGF axis and programmed cell death. Immunology and Cell Biology 77 256-262. (doi:10.1046/j.14401711.1999.00822.x)

Cao LQ, Chen XL, Wang Q, Huang XH, Zhen MC, Zhang LJ, Wen LI \& Jiong BI 2007 Upregulation of PTEN involved in rosiglitazone-induced apoptosis in human hepatocellular carcinoma cells. Acta Pharmacologica Sinica 6 879-887. (doi:10.1111/j.1745-7254.2007.00571.x)

Coyral-Castle S, Rame C, Fatet A \& Dupont J 2010 Effects of unsaturated fatty acids on progesterone secretion and selected protein kinases in goat granulosa cells. Domestic Animal Endocrinology 38 272-283. (doi:10.1016/j.domaniend.2009.12.002)

Derecka K, Sheldrick EL, Wathes DC, Abayasekara DRE \& Flint APF 2008 A PPAR-independent pathway to PUFA-induced COX-2 expression. Molecular and Cellular Endocrinology 287 65-71. (doi:10.1016/j.mce. 2008.02.015)

Devery R, Miller A \& Stanton C 2001 Conjugated linoleic acid and oxidative behaviour in cancer cells. Biochemical Society Transactions $\mathbf{2 9}$ 341-344. (doi:10.1042/BST0290341)

Ehrmann DA, Schneider DJ, Sobel BE, Cavaghan MK, Imperial J, Rosenfield RL \& Polonsky KS 1997 Troglitazone improves defects in insulin action, insulin secretion, ovarian steroidogenesis, and fibrinolysis in women with polycystic ovary syndrome. Journal of Clinical Endocrinology and Metabolism 82 2108-2116. (doi:10.1210/jc.82.7. 2108)
Fernandez-Fernandez R, Martini AC, Navarro VM, Castellano JM, Dieguez C, Aguilar E, Pinilla L \& Tena-Sempere M 2006 Novel signals for the integration of energy balance and reproduction. Molecular and Cellular Endocrinology 254 127-132. (doi:10.1016/j.mce.2006.04.026)

Gygi SP, Rochon Y, Franza BR \& Aebersold R 1999 Correlation between protein and mRNA abundance in yeast. Molecular and Cellular Biology 19 1720-1730.

Houseknecht KL, Vanden Heuvel JP, Moya-Camarena SY, Portocarrero CP, Peck LW, Nickel KP \& Belury MA 1998 Dietary conjugated linoleic acid normalizes impaired glucose tolerance in the Zucker diabetic fatty $\mathrm{fa} / \mathrm{fa}$ rat. Biochemical and Biophysical Research Communications 244 678-682. (doi:10.1006/bbrc.1998.8303)

Kepler CR, Tucker WP \& Tove SB 1970 Biohydrogenation of unsaturated fatty acids, IV. Substrate specificity and inhibition of linoleate $\delta$-12-cis, $\delta$-11-trans-isomerase from Butyrivibrio fibrisolvens. Journal of Biological Chemistry 245 3612-3620.

Kim EJ, Kang IJ, Cho HJ, Kim WK, Ha YL \& Park JHY 2003 Conjugated linoleic acid downregulates insulin-like growth factor-I receptor levels in HT-29 human colon cancer cells. Journal of Nutrition 133 2675-2681.

Komar CM 2005 Peroxisome proliferator-activated receptors (PPARs) and ovarian function - implications for regulating steroidogenesis, differentiation, and tissue remodeling. Reproductive Biology and Endocrinology 3 41. (doi:10.1186/1477-7827-3-41)

Lee KN, Kritchevsky D \& Pariza MW 1994 Conjugated linoleic acid and atherosclerosis in rabbits. Atherosclerosis 108 19-25. (doi:10.1016/ 0021-9150(94)90034-5)

Lee SY, Hur GY, Jung KH, Jung HC, Lee SY, Kim JH, Shin C, Shim JJ, In KH, Kang KH et al. 2006 PPAR- $\gamma$ agonist increase gefitinib's antitumor activity through PTEN expression. Lung Cancer 51 297-301. (doi:10. 1016/j.lungcan.2005.10.010)

Leroy JL, Vanholder T, Van knegsel AT, Garcia-Ispierto I \& Bols PE 2008 Nutrient prioritization in dairy cow early postpartum: mismatch between metabolism and fertility? Reproduction in Domestic Animals 43 96-103. (doi:10.1111/j.1439-0531.2008.01148.x)

Maehama T \& Dixon JE 1998 The tumor suppressor, PTEN/MMAC1, dephosphorylates the lipid second messenger, phosphatidylinositol 3,4,5-trisphosphate. Journal of Biological Chemistry 273 13375-13378. (doi:10.1074/jbc.273.22.13375)

Marei WF, Wathes DC \& Fouladi-Nashta AA 2009 The effect of linolenic acid on bovine oocyte maturation and development. Biology of Reproduction 81 1064-1072. (doi:10.1095/biolreprod.109.076851)

Mitwally MFM, Kuscu NK \& Yalcinkaya TM 1999 High ovulatory rates with use of troglitazone in clomiphene-resistant women with polycystic ovary syndrome. Human Reproduction 14 2700-2703. (doi:10.1093/humrep/ 14.11.2700)

Monga R, Sharma I, Datta TK \& Singh D 2011 Characterization of serumfree buffalo granulosa cell culture and analysis of genes involved in terminal differentiation from $\mathrm{FSH}$ - to LH-responsive phenotype. Domestic Animal Endocrinology 41 195-201. (doi:10.1016/j.domaniend.2011.07.001)

Murugan MA, Fenwick MA, Cheng Z, Sharma MK, Singh D \& Wathes DC 2010 IGF1 induces up-regulation of steroidogenic and apoptotic regulatory genes via activation of phosphatidylinositol-dependent kinase/AKT in bovine granulosa cells. Reproduction 139 139-151. (doi:10.1530/REP-09-0050)

Nicolosi RJ, Rogers EJ, Kritchevsky D, Scimeca JA \& Huth PJ 1997 Dietary conjugated linoleic acid reduces plasma lipoproteins and early aortic atherosclerosis in hypercholesterolemic hamsters. Artery 22 266-277.

Odens LJ, Burgos R, Innocenti M, VanBaale MJ \& Baumgard LH 2007 Effects of varying doses of supplemental conjugated linoleic acid on production and energetic variables during the transition period. Journal of Dairy Science 90 293-305. (doi:10.3168/jds.S0022-0302 (07)72630-9)

Orsi NM, Gopichandran N, Leese HJ, Picton HM \& Harris SE 2005 Fluctuations in bovine ovarian follicular fluid composition throughout the oestrous cycle. Reproduction 129 219-228. (doi:10.1530/rep.1. 00460)

Park Y, Albright KJ, Liu W, Storkson JM, Cook ME \& Pariza MW 1997 Effect of conjugated linoleic acid on body composition in mice. Lipids 32 853-858. (doi:10.1007/s11745-997-0109-x) 
Pariza MW, Park Y \& Cook ME 2001 The biologically active isomers of conjugated linoleic acid. Progress in Lipid Research 40 283-298. (doi:10.1016/S0163-7827(01)00008-X)

Poretsky L, Cataldo NA, Rosenwaks Z \& Giudice LC 1999 The insulinrelated ovarian regulatory system in health and disease. Endocrine Reviews 20 535-582. (doi:10.1210/er.20.4.535)

Renaville B, Bacciu N, Comin A, Motta M, Poli I, Vanini G \& Prandi A 2008 Plasma and follicular fluid fatty acid profiles in dairy cows. Reproduction in Domestic Animals 45 118-121. (doi:10.1111/j.1439-0531.2008. 01264.x)

Revelli A, Delle Piane L, Casano S, Molinari E, Massobrio M \& Rinaudo P 2009 Follicular fluid content and oocyte quality: from single biochemical markers to metabolomics. Reproductive Biology and Endocrinology 4 7-40. (doi:10.1186/1477-7827-7-40)

Rimon E, Sasson R, Dantes A, Land-Bracha A \& Amsterdam A 2004 Gonadotropin induced gene regulation in human granulosa cells obtained from IVF patients: modulation of genes coding for growth factors and their receptors and genes involved in cancer and other diseases. International Journal of Oncology 24 1325-1338.

Rubenstrunk A, Hanf R, Hum DW, Fruchart JC \& Staels B 2007 Safety issues and prospects for future generations of PPAR modulator. Biochimica et Biophysica Acta 1771 1065-1081. (doi:10.1016/j.bbalip.2007.02.003)

Schmidt MW, Houseman A, Ivanov AR \& Wolf DA 2007 Comparative proteomic and transcriptomic profiling of the fission yeast Schizosaccharomyces pombe. Molecular Systems Biology 3 79. (doi:10.1038/ msb4100117)

Seargent JM, Yates EA \& Gill JH 2004 GW9662, a potent antagonist of PPAR $\gamma$, inhibits growth of breast tumour cells and promotes the anticancer effects of the PPAR $\gamma$ agonist rosiglitazone, independently of PPAR $\gamma$ activation. British Journal of Pharmacology 143 933-937. (doi:10.1038/sj.bjp.0705973)

Sinclair KD, Lunn LA, Kwong WY, Wonnacott K, Linforth RS \& Craigon J 2008 Amino acid and fatty acid composition of follicular fluid as predictors of in-vitro embryo development. Reproductive Biomedicine Online 16 859-868. (doi:10.1016/S1472-6483(10)60153-8)

Singh R \& Sinclair KD 2007 Metabolomics: approaches to assessing oocyte and embryo quality. Theriogenology 68 56-62. (doi:10.1016/j.theriogenology.2007.04.007)

Von Soosten D, Meyer U, Weber EM, Rehage J, Flachowsky G \& Dänicke S 2011 Effect of trans-10, cis-12 conjugated linoleic acid on performance, adipose depot weights, and liver weight in early-lactation dairy cows. Journal of Dairy Science 94 62859-62870. (doi:10.3168/jds.2010-3851)

Yi HK, Kim SY, Hwang PH, Kim CY, Yang DH, Oh Y \& Lee DY 2005 Impact of PTEN on the expression of insulin-like growth factors (IGFs) and IGF-binding proteins in human gastric adenocarcinoma cells. Biochemical and Biophysical Research Communications 330 760-776. (doi:10.1016/j.bbrc.2005.03.045)

Received 6 March 2012

First decision 27 March 2012

Revised manuscript received 14 June 2012

Accepted 22 June 2012 